\title{
12 Revising labour law for work
}

\author{
Judy Fudge
}

\section{Introduction: can labour law make a contribution?}

Should people who sort through trash for a living in the outskirts of Cape Town, Kolkata and Buenos Aires be entitled to bargain collectively with the purchasers of their cull or with municipal governments for access to waste and the right to bid for solid waste management contracts? How do we provide street vendors in Nairobi with maternity pay? Should Uber drivers or self-employed domiciliary care workers be entitled to the minimum wage and to the right to participate in collective bargaining over the conditions of their work?

The broad question that unites these specific examples is whether it is possible to develop a basis for regulating work that can operate in a wide range of settings across different levels of economic development. Labour law is simply one strand in a complex mix of regulations, including municipal bylaws and sectoral economic policies, that shape the standards of living and life chances of informal workers. However, if law and public policies continue to draw the boundaries of labour rights and standards by reference to the contract of (formal) employment, the vast majority of informal workers will continue to be excluded from these basic rights and protections.

Moreover, the divide between an employment contract and other work relations has always presented particular difficulties for women. There is a fundamental mismatch between the law's binary divide and many women's experience, in which the boundaries between paid and unpaid work, formal and informal work, and between the labour market and social security are permeable and shifting. The effects of this mismatch are particularly felt among those women homeworkers and other sub-contracted women informal workers, as well as women who perform domiciliary care, These women workers often find themselves characterised as "independent" or "quasi-independent" despite the reality of their lack of real autonomy or self-sufficiency in the market.

\section{The regulation of work}

The standard employment relationship emerged as one of the key institutions of labour markets in industrialised democracies in the first half of the twentieth 
century. It took the legal form of the contract of employment, and its function is to link workers' subordination to managerial prerogatives to protections against the abuse of this power. Through the contract of employment, labour law is also linked to other areas of regulation such as social security, tax and corporate law, which, in turn, protect workers against a range of social risks through various mechanisms of redistribution (Fudge 2017).

Changes in production and the ways in which firms pursue "flexible" forms of labour, such as casual labour, contract labour, outsourcing, homeworking, and other forms of sub-contracting have led to a proliferation of employment and work relations and activities that do not depend upon a contract of employment. Consequently, they are beyond the scope of labour law and its associated labour standards and techniques of regulation, such as collective bargaining. Moreover, the prediction that the informal workforce would be absorbed into the formal economy as economies modernised has proven to be incorrect. In fact, in developing and developed countries, the informal economy has persisted and onceformal jobs have been informalised, with the result that the majority of workers are in low-skilled, poorly paid, intermittent and insecure employment.

Given the limited coverage of the contract of employment, we need to consider a range of platforms for providing labour rights and standards (Fudge, McCrystal and Sankaran 2012). This regulation of work would include the traditional techniques, such as collective bargaining, and substantive and procedural laws, but would be expanded to include a wide range of regulatory techniques, such as licensing.

In some cases, the regulation of work would be similar in many respects to the traditional forms of labour law as it would focus on work as a relationship between an "employing entity" - an employer, a retailer, a supplier, purchaser or some sort of entity that exercises either economic or labour process control over the worker. Here we can think of work as a relationship. However, in other contexts, such as street vendors who do not depend upon one or two suppliers, or self-employed seamstresses, there is no entity that exercises direct control over the worker's performance. In these cases, it is important to find other platforms and techniques for regulating work and protecting workers than those traditionally associated with labour law.

Policy-making needs to look for functional equivalents to the institutional role that the employer played in the standard employment relationship. The idea is to go beyond the form of an institution and look at its function since there are a number of different institutions that can serve a particular function (Marshall 2016).

\section{Work as a relationship: beyond contract}

An important suggestion is to focus on the regulation of personal work relations (Freedland and Kountouris 2011). The benefit of this approach is that work relations are no longer seen solely in terms of the subordinated employee, and its alter ego, the independent contractor. The regulation of personal work arrangements must be detached from its anchor in the contract of employment. It is also 
critical to move away from a map of personal work relations that depicts them as a series of concentric circles with the contract of employment at its core since this map serves to reinforce, rather than diminish, the hold of the contract as the foundation of labour law.

The regulation of work relations should be centred on the worker (Freedland and Kountouris 2011: 339). The foundational concept is the personal work relation, which is defined as a connection or set of connections, between a worker and another person(s) or organisation(s) arising from an engagement or arrangement for the carrying out of work or the rendering of service or services by the workers personally (ibid.: 31). This conception is narrower than work since there must be a relationship and not simply an activity, and it requires that the worker be personally involved in performing the work.

\section{Work as an activity: beyond relationship}

Focusing on the relationship with an employer or entity that is functionally equivalent to an employer leaves out not just the reality of independent selfemployed workers, but also the possibility of other or shared sources of responsibility, including the state, mutual funds which spread the cost among all parties involved and even private insurance. Once the focus is on the worker and her activities, rather than on the contractual relationship, it is possible to begin to consider a range of ways for dealing with social and economic risks, and not simply employment risk. One way forward is to regard maternity benefits as simply a matter for social security, which is the approach adopted by the International Labour Organization (ILO) (the Maternity Protection Convention, 2000 (No. 183)). Economic risks run the gamut from harassment to bribery and eviction, and here insurance schemes need to be combined with initiatives designed to cultivate transparency and accountability in public institutions. For some informal workers, a guaranteed annual income, sometimes known as a citizenship or basic income, and which has been discussed as a policy reform for over 30 years, may be more suitable than unemployment insurance for dealing with risks to income (McKay 2007).

In the case of health and safety for informal workers, who are engaged in economic activities without a relationship to an entity that controls either their labour process or the space where the work is performed, it is crucial to consider functional equivalents. For street vendors and waste pickers, the municipality, which controls the use of public space and waste and has a tax base, may be the appropriate entity. Health and safety interventions will require innovative low cost work organisation and engineering solutions from occupational hygienists and occupational medicine specialists. Since informal workers will be unable to afford these costs, local government and the formal private sector may have to contribute to these costs under a broader umbrella of health protection (Lund and Naidoo 2016). 


\section{Collective bargaining, social dialogue and empowerment}

Collective representation of informal workers is critical both in terms of shaping the workers' self-interests as workers and for aggregating and articulating their needs and interests. The ILO defines the term "social dialogue" to include "all types of negotiation, consultation or information sharing either among the bipartite parties in the workplace or industrial sector, or by tripartite partners at the national level, on issues of common interest" (Ebisui 2012: 4). Collective bargaining is one, but not the only, form of social dialogue. Moreover, social dialogue structures need to move from traditional tripartite to broader-based dialogue institutions (Sankaran 2016).

There are a variety of organisational forms that can represent informal workers, though the critical ones must be membership-based in order to cultivate accountability of the organisation to the informal workers. There are three key types of different forms of membership-based organisations, and these different forms overlap (Budlender 2013):

1 Unions represent workers with the goal of engaging in collective bargaining on their behalf with corporate enterprises, workers' cooperatives and public authorities that directly or indirectly employ workers or impact their work.

2 Worker cooperatives are a form of enterprise that is owned and democratically controlled by their members, who may either be employed as wage workers or as self-employed.

3 Associations are membership-based groups that typically do not engage in collective bargaining with a direct employer.

The main counterparts of these informal workers' organisations are large companies, employer associations, the state or central governments, municipalities, the police and employers. Thus, it is critical for informal workers' organisations to identify the entity or authority most responsible for the issues over which they wish to negotiate and that the identified entity then becomes the negotiating partner (Carré, Horn and Bonner 2018). It is also important to recognise that the negotiating partner may differ for different issues even for a single group of workers.

\section{Conclusion}

In order to regulate to improve and formalise informal work, it is imperative to adopt a strategic conception of work regulation. Its starting point should be the dominant actors and social activities bound up in work relations and not the existing legal categories of employee, worker or independent contractor nor on pre-existing legal jurisdictions, such as labour, immigration, housing and planning law (Fudge and McCann 2015; von Broembsen and Godfrey 2016). Regulatory power, understood as measures or interventions that seek to change the behaviour of individuals or groups, is not held solely by governments but dis- 
persed throughout a number of bodies or groups, such as firms, nongovernmental and supra-governmental agencies, standard-setting organisations, credit-rating agencies, business and professional associations, trade unions, religious organisations, courts, and others. Successful regulatory strategies must engage with economic and social actors whose behaviour is the subject of regulation with the broader goal of building capacities in order to ensure that labour market actors internalise norms. In turn, this would ensure the sustainability of regulatory interventions to improve the terms and conditions under which informal workers work. 